\title{
PERSON-CENTERED TECHNOLOGY OF COLLABORATIVE EDUCATION
}

\author{
Gulnoz Ergashevna Turaeva
}

Teacher of The Department Of Primary Education, Termez State University, Termez, Uzbekistan

\section{ABSTRACT}

This article is based on the experience of well-known Uzbek, Russian and foreign educators, namely: A. Avloni, Fitrat, H. H. Niyazi, K. D. Ushinsky, N. P. Pirogov, L. N. Tolstoy, Ya..Korshak, V.A. Sukhomlinsky, K.D. Makarenko, S.T. Shatsky, Y.A. Kamensky, J.J. Russo, K. Rodgers, E. Bern and others.

KEYWORDS: - Education, training, outcome, efficiency, culture, process, activity, opportunity, collaboration, idea, technology, problem, attitude, success, communication, knowledge, skill, qualification, competence, ability, quality, factor, approach, content.

\section{INTRODUCTION}

The main processes of collaborative parenting include: sharing ideas, talking, analyzing, discussing, negotiating, giving practical assignments, completing practical tasks, making something, and more. In the organization of joint educational classes: teacher-audience, teachergroup, teacher-large group, teacher-student, student-student, small group-small group, small group-audience and other organizational forms are used.

Collaborative nurturing is a popular term that refers to instructional and interactive processes in the implementation of mutually supportive collaboration between students as well as the teacher's ability to interact effectively with a group of students, individually and as a whole, in the educational process. Students collaborate on academic assignments in small groups, helping themselves and their peers in their groups together.

Collaborative pedagogy began to develop in the 1980s and brought to life many innovative processes in education. At the heart of this technology is the experience of well-known Uzbek, Russian and foreign teachers. They are A.Avloni, Fitrat, H.H.Niyazi, K.D.Ushinsky, N.P.Pirogov, L.N.Tolstoy, Ya.Korshak, V.A.Sukhomlinsky, K.D.Makarenko, S.T. .Shatsky, J.A. Kamensky, J.J. Russo, K. Rodgers, E. Bern and others.

Collaborative pedagogy is carried out in 4 main directions:

- approach to the person as a person;

- dialectical activating and developing complex;

- the concept of education;

- adapting the environment to education. 
CURRENT RESEARCH JOURNAL OF PEDAGOGICS 2(8): 68-71, August

2021 DOI: https://doi.org/10.37547/pedagogics-crjp-02-08-15

ISSN 2767-3278

(C)2021 Master Journals

\section{Crossref doi) 81 Google}

Accepted $26^{\text {th }}$ August, 2021 \& Published $31^{\text {th }}$ August, 2021

Collaborative teaching methods have the following 5 features:

1. Students work together on a common assignment or activity being taught, which is best mastered through group work.

2. Students work together in small groups of 3-5 members.

3. Students adhere to behavioral criteria developed by the group and socially accepted in order to find solutions to common tasks or to carry out learning activities.

4. Students will be positive and independent. Achieving solutions to common tasks or organizing work on learning activities will be structured to take into account the need for students to support each other.

5. Students are personally responsible and accountable for the results of their work, or in other words, for learning, education.

Collaborative education allows you to achieve the following results:

- Enriches the student's upbringing process;

- Provides students with a set of cognitive information that is distributed and mastered among them;

- Stimulates students to learn the material;

- Expands students 'opportunities to shape their personal knowledge, skills, competencies, and worldviews;

- Increases the efficiency of two-way information exchange;

- Provides students with the necessary education to prepare for independent living;

- Promotes positive interactions between different cultures and socio-economic groups.

Cooperation is a situation in which the object and the subject come together, friendship, mutual assistance, community emerges.
- The basis of collaborative pedagogy is:

- Comprehensive knowledge of the student's personality;

- A humane approach to the student's personality;

- Public education;

- High professional potential of the teacher;

- Focus community attention on the institution of higher education;

- Considering collaborative pedagogy as a manifestation of advanced pedagogy.

The concept of collaborative pedagogy is as follows:

a) cooperation with the student;

b) creating positive emotional satisfaction in the student;

c) successful implementation of higher education;

d) work with students and convince them to succeed;

e) the idea of helping the student;

f) every student should be able to freely participate in group work.

g) evaluation of student work, ie incentives, etc.

There is a system of classifying lessons based on collaborative learning technology and applying them in practice, and below are some examples of these lessons:

a) three-stage interview; b) roundtable discussion; c) compiling a list; d) organization of problem solving; e) one-minute works; f) pair comments; g) send the problem; h) evaluation line; i) rare unit; j) community box k) two-part diary; l) mutual questioning, etc.

Many of these types of activities involve dividing students into small groups and assigning roles and tasks to them. The specific psychological, 
CURRENT RESEARCH JOURNAL OF PEDAGOGICS 2(8): 68-71, August

2021 DOI: https://doi.org/10.37547/pedagogics-crjp-02-08-15

ISSN 2767-3278

(C)2021 Master Journals

\section{Crossref doi) 81 Google}

Accepted $26^{\text {th }}$ August, 2021 \& Published 31 th August, 2021

pedagogical, methodical, didactic bases of effective use of educational technologies are developed in cooperation, which are:

a) organizational and pedagogical bases - the definition of opportunities for collaboration of participants on the basis of the curriculum, program, subject, requirements of the state educational standard and the amount of new knowledge, skills, competencies required to master them in accordance with them increase;

b) psychological bases - taking into account the psychological and age characteristics of students, creating a favorable psychological environment for each student in the classroom, ensuring that students understand the subject, concepts, terms, definitions, formulas and other conditions used in the quality of free communication;

c) methodological bases - pre-work preparation of the necessary tools for training, ensuring their quality at the required level. Organization of effective use of communication methods and innovative information technologies, etc.

d) didactic basis - to ensure which principle of didactics should be used in describing the topic of each lesson.

Factors ensuring the effectiveness of joint education:

a) creative approach of students to the content of the lesson; b) analyze and critique the information in the course, justify their conclusions; c) creative application of knowledge, skills and competencies in new situations; g) allocating more time for practical assignments, helping co-taught students to succeed in each other, and so on.

It is well known that collaborative nurturing technologies have great potential in improving a student's creative ability.

The following qualities of a teacher as a factor of teacher's behavior have a great influence on the development of creative abilities in students:

a) social thinking; b) recognition of dignity; c) developing students' awareness of the environment; d) focus on the free possession of ideas and objects; e) develop the ability to provide informed information about creative processes; f) develop the ability to critically justify; g) encourage self-esteem; h) teaching how to control the feeling of fear of how to get an assessment, etc.

The following factors of teacher behavior in the development of creative abilities in students have a negative impact on creativity in students:

a) authoritarian order, setting requirements; b) the authoritarian nature of the environment; c) teacher rigidity; d) rough assessment; e) laughing at the student; f) the use of perseverance to achieve a certain success; g) hostility towards the person, etc.

Collaboration between students, teachers, university leaders, parents and the community is the basis of collaborative pedagogy. The classification of collaborative pedagogy is as follows:

1. Metatechnology is a general program of modern educational technology.

2. The philosophical core consists of humanism and human philosophy.

3. Methodological approach: communicative, person-centered, socio-cultural, businesslike.

4. Leading factors of development: biologicalsocial-psychological.

5. Purpose: to promote the ideas of educator, creator, humanist, general professional, general educational.

6. Social pedagogical activity: educational, psychological, pedagogical, social.

7. Type of management of the educational process: small group and individual. 
CURRENT RESEARCH JOURNAL OF PEDAGOGICS 2(8): 68-71, August

2021 DOI: https://doi.org/10.37547/pedagogics-crjp-02-08-15

ISSN 2767-3278

(C)2021 Master Journals

Crossref dof 81 Google

Accepted 26 $6^{\text {th }}$ August, 2021 \& Published 31 ${ }^{\text {th }}$ August, 2021

8. Interpersonal educative description and student approach: human and personal.

9. Methods: problem-solving, creative, dialogue, game.

10. The direction of the program: on the basis of humanism and democracy.

Target areas for pedagogical cooperation:

1. Transition from pedagogical demand to pedagogical approach.

2. A humane and personal approach to the student.

3. The law of educational unity

There are 6 ways to approach a person, they are:

a) love; b) understanding; c) acceptance; g) care; d) empathy; e) assistance.

Today's rapidly changing social, economic and cultural life requires the widespread use of new pedagogical interactive methods in shaping students' worldviews. Conducting traditional classes is gradually giving way to intensive and interactive methods, non-traditional classes.

The stronger the knowledge, the more the student's worldview, intellectual potential develops and matures. Today, information literacy for students is an important condition for improving the effectiveness of education. In accordance with the requirements of the state educational standard set for higher education institutions, which are the fifth link in the system of continuing education, these educational institutions develop a harmoniously developed person who is loyal, respects national and universal values, can think creatively and independently, feels his duty and responsibility to the state, society and family, and instills the national idea in their minds and hearts by increasing the efficiency of the educational process, implementing the latest achievements of science.
Successful solution of these tasks requires the use of modern educational technologies in the educational process. The use of modern pedagogical technologies in the educational process requires, first of all, the humanization of pedagogical relations. Because any technology used without it will not give the expected effect.

\section{REFERENCES}

1. Karimov I.A. High spirituality is an invincible force. - $\mathrm{T}$.: Manaviyat, 2008.

2. Mirziyoev Sh.M. We will build a free and prosperous democratic Uzbekistan together with our brave and noble people. «Xalq so'zi» newspaper, December 15, 2015.

3. Питюков В. Ю. Основы педагогической технологии. М .: Гном - Пресс, 1999.

4. Поульсен С. Знакомство с современными методами приготовления. Пер.с дацкого языка.-Б .: Кесип, 2007.

5. Селевко Г.К. Современные образовательные технологии. Народное образование, 1998.

6. Farfieva, K. A. (2021). Theoretical Fundamentals of Scientific And Innovative Thinking In Adolescents. The American Journal of Social Science and Education Innovations, 3(04), 431-437.

7. Фарфиева К.А. Замонавий ахборот воситаларини ўспиринлар илмий инновацион тафаккурининг ривожланишига таъсири. Инновацион ривожланишда ижтимоий-гуманитар фанларнинг долзарб масалалари. Жиззах: ЖизПИ, 2020. - Б. 243-246. 